\title{
PENGARUH KEPEMIMPINAN TERHADAP KINERJA DOSEN DI PERGURUAN TINGGI
}

\author{
Purwanto S.K. \\ Program Studi Magister Manajemen-Universitas Mercu Buana Jakarta \\ Email: purwanto@mercubuana.ac.id
}

\begin{abstract}
Abstrak. Daya saing suatu bangsa ditentukan oleh kualitas pendidikan tinggi, terutama dalam teknologi dan inovasi. Peningkatan kualitas pendidikan tinggi terkait dengan kinerja dosen dalam bidang pendidikan, penelitian dan publikasi, serta pengabdian kepada masyarakat. Peningkatan kinerja dosen memerlukan kompetensi dan komitmen dari pimpinan universitas. Pemimpin di perguruan tinggi harus membuat iklim organisasi yang baik untuk menumbuhkan rasa memiliki dari dosennya serta pendidikan dan pelatihan untuk meningakatkan kompetensi dosennya. Penelitian ini bertujuan untuk mengetahui dampak dari kepemimpinan terhadap kinerja dosen. Penelitian dilakukan di universitas negeri dan swasta di Jakarta dengan sampel dari 60 dosen. Hasil penelitian menunjukkan bahwa kepemimpinan dalam pendidikan tinggi yang dapat meningkatkan kinerja dosen. Variabel yang berpengarih nyata adalah kemampuan memberikan teladan, membuat keputusan dengan cepat, memberikan delegasi wewenang, dan tingkat optimisme yang tinggi.
\end{abstract}

Kata kunci: Kepemimpinan, Kinerja, Dosen, Perguruan Tinggi

\begin{abstract}
The Competitiveness of a nation is determined by the quality of higher education, especially in the technological and innovation. Improving the quality of higher education related to the performance lecturer in the areas of education, research and publications, and community service. Lecturer performance improvement requires the competence and commitment of university leadership. A leader in university must make a good organizational climate especially education and training that engagement and developed in its members. This study aims to determine the impact of leadership on the performance of lecturers. The study was conducted at state and private universities in Jakarta with a sample of 60 lecturers. The results showed that leadership in higher education that can improve the performance of the lecturer. Variables significant are able to provide exemplary leadership, make decisions quickly, giving delegates the authority, and a high level of optimism.
\end{abstract}

Keywords: Leadership, Performance, Lecturer, Higher Education.

\section{PENDAHULUAN}

Laporan daya saing global atau Global Competitiveness Report (Schwab, 2012) menunjukkan bahwa daya saing menjadi kata kunci dalam menghadapi persaingan bebas baik AFTA (Asean Free Trade Area) maupun komunitas ekonomi lainnya. Data dari The Global Competitiveness Report, menunjukkan peringkat daya saing Indonesia cukup mengalami penurunan dari tahun ke tahun. Posisi Indonesia menempati urutan 54 dari 
133 negara tahun 2009, kemudian pada 2010 menjadi urutan 44 dari 139 negara dan posisi ini menurun terus menjadi 45 tahun 2011 dan menempati urutan ke 50 dari 144 negara.

Beberapa komponen daya saing sangat terkait dengan pendidikan tinggi seperti pendidikan tinggi dan pelatihan, fleksibilitas dan efisiensi pasar tenaga kerja, kesiapan teknologi dan inovasi. Langitan (2012) menyatakan bahwa daya saing perguruan tinggi perlu mendapatan perhatian karena indeks daya saing perguruan tinggi Indonesia juga rendah yaitu berada pada tingkat ke 69 dari 140 negara, daya saing kesiapan teknologi berada pada peringkat ke 94 dan tingkat inovasi ke 36. Dengan demikian terdapat korelasi antara daya saing perguruan tinggi dan Negara.

Menurut Brodjonegoro (2008) untuk meningkatkan daya saing dan mutu perguruan tinggi, maka perlu diupayakan adanya indikator kinerja perguruan tinggi, yang diukur yaitu: kuantitas dan kualitas serta relevansi lulusan, (b) kuantitas dan kualitas serta relevansi hasil penelitian dan pengembangan, dan (c) kuantitas dan kualitas dan relevansi kegiatan pengabdian pada masyarakat dimana semua aktivitas tersebut terkait dengan kinerja dosen dalam tridarma perguruan tinggi. Perguruan Tinggi mampu memberikan kontribusi yang positif dalam peningkatan daya saing bangsa apabila organisasi perguruan tinggi tersebut sehat. Ciri-ciri perguruan tinggi yang sehat adalah meliputi: (a) mampu melakukan jaminan kualitas (Quality Assurance, (b) mempunyai kewenangan atau otonomi (Autonomy), (c) memiliki jiwa kewirausahaan atau (Enterpreneurialism) dan (d). kepemimpinan yang kuat (Leadership). Jaminan mutu dalam perguruan tinggi seperti akreditasi baik internal maupun ekstrenal merupakan kegiatan yang terinstitusi dalam bentuk prosedur standar organisasi yang melibatkan pihak luar. Otonomi perguruan tinggi merupakan kebebasan pimpinan perguruan tinggi untuk mengelola institusi selama tidak bertentangan dengan undang-undang. Jiwa kewirausahaan merupakan kemampuan institusi dalam pengelola dan mencari dana melalui proyek-proyek penelitian dan pengabdian masyarakat bekerja sama dengan dunia usaha; serta kepemimpinan yang cakap dan bertanggung jawab.

Menurut laporan Scimago (2013) tentang peringkat dari publikasi jurnal antar negara, maka untuk kawasan Asia, Indonesia berada pada peringkat ke 11 dibandingkan Thailand pada peringkat ke-9, Malaysia ke-8 dan Singapura ke-7. Jumlah dokumen yang dipublikasikan Indonesia mencapai 16.000 sedangkan Thailand mencapai 69.000, Malaysia mencapai 75.000 dan Singapura mencapai 126.000. Rendahnya produktivitas jurnal ini menunjukkan adanya masalah dalam kinerja dosen terutama dalam bidang penelitian dan publikasi ilmiah. Rendahnya masalah kinerja dosen terkait dengan penelitian dan publikasi disebabkan banyak faktor seperti kompetensi dan komitmen atau motivasi. Kompetensi ini menyangkut pendidikan baik $S_{2}$ dan $S_{3}$, kemampuan metodologi dan kajian pustaka, serta penguasaan teknologi. Faktor komitmen dan motivasi masih banyak bergerak pada faktor kompensasi atau imbalan sebagai kebutuhan dasar manusia. Namun demikian, faktor motivasi tidak sekedar faktor imbalan, tetapi juga bagaimana motivasi dibangun atas komitmen organsasi dimana setiap dosen merasa memiliki organisasi dan bangga menjadi bagian organisasi yang maju dan berdaya saing (Meyer dan Herscovitch, 2001).

Masalah komitmen dalam kajian ilmu manajemen sumberdaya manusia sangat terkait dengan bagaimana membuat para dosen atau anggota organisasi tumbuh rasa memiliki (engagement) di dalam dirinya (Susbandono, 2011). Masalah komitmen dan Engagement menurut Susbandono (2011) dimulai dari Pemimpin (leaders). Seorang pemimpin harus membuat iklim organisasi yang baik agar engagement lahir dan 
berkembang dalam diri para anggotanya. Seorang pemimpin harus walk the talk, trusttrustworthy, care, visioner, punya character dan competency. Komitmen ini mencakup: (a) komitmen afektif (affective commitment), yaitu: keterlibatan emosional seseorang pada organisasinya berupa perasan cinta pada organisasi, (b) komitmen kontinyu (continuance commitment), yaitu: persepsi seseorang atas biaya dan resiko dengan meninggalkan organisasi saat ini dimana terdapat dua aspek pada komitmen kontinyu, yaitu: melibatkan pengorbanan pribadi apabila meninggalkan organisasi dan ketiadaan alternatif yang tersedia bagi orang tersebut, dan (c) komitmen normatif (normative commitment) yaitu: sebuah dimensi moral yang didasarkan pada perasaan wajib dan tanggung jawab pada organisasi yang mempekerjakannya.

Besarnya peranan pemimpin dalam perguruan tinggi terkait dengan kinerja SDM terutama dosen juga di kemukakan oleh Bachtiar (2013). Bachtiar (2013) mengemukakan bahwa banyak faktor penentu daya saing perguruan tinggi, namun yang paling menentukan adalah kepemimpinan yang cakap dan bertanggung jawap, baik pada tingkat universitas maupun pada tingkat fakultas dan program studi. Beberapa alasan pentingnya kepemimpinan perguruan tinggi adalah: (a) pimpinan yang berperan mempromosikan kompetensi institusi pada masayarakat, (b) pimpinan yang mendesain sistem recruitment staf akademik dan mahasiswa baru, (c) pimpinan yang memberikan motivasi dan kewenangan pada ketua program studi untuk mengembangkan program studinya, (d) pimpinan yang memperbaiki atmosfir akademik dan kondisi kerja, dan (e) pimpinan yang menyatukan kepentingan dan minat yang beragam dalam proses belajar mengajar.

Berdasarkan pada uraian pada latar belakang, maka rumusan masalah dalam penelitian ini adalah: (a) Bagaimana pengaruh kepemimpinan terhadap kinerja dosen yang terkait dengan tridarma perguruan tinggi, dan (b) Faktor-faktor kepemimpinan apa saja yang yang berpengaruh terhadap kinerja dosen. Tujuan dari penelitian ini adalah: (a) mengetahui pengaruh kepemimpinan perguruan tinggi dalam peningkatan kinerja dosen, dan (b) mengetahui faktor-faktor kepemimpinan yang mampu meningkatkan kinerja tridarma bagi dosen di perguruan tinggi.

\section{KAJIAN TEORI}

Hubungan kepemimpinan dengan kinerja adalah sangat erat (Hughes et. al, 2002). Menurut Yukl (2005) kepemimpinan diharapkan dapat memberikan visi yang memberi inpirasi untuk meningkatkan komitmen SDM sehingga bermuara pada peningkatan kualitas dan produktivitas yang pada akhirnya pada tingkat keuntungan dan daya saing. Disisi lain, kepemimpinan juga diharapkan dapat memberikan latihan dan bimbingan kepada SDM untuk meningkatkan ketrampilan SDM atau kompetensi sehingga kualitas dan produktivitas meningkat (Bass 2000).

Kepemimpinan menurut definisi Javidan et. al (2006) dalam GLOBE Project, adalah kemampuan dari seorang individu untuk mempengaruhi, memotivasi, dan memungkinkan karyawan untuk berkontribusi secara efektif dan sukses dari organisasi di mana karyawan menjadi anggotanya. Hamilton (2005) pemimpin adalah seseorang yang melangkah ke depan memberi petunjuk dan jalan, mempengaruhi, selalu mencari, mendengarkan, dan mengharapkan serta bertindak untuk kondisi masa depan yang lebih baik. Di sisi lain, menurut Schimmoeller (2006) pemimpin adalah seseorang yang fokus pada tujuan organisasi dan bagaimana mencapai tujuan tersebut, dan fokus pada hubungan atasan dan bawahan dalam jangka panjang untuk menjaga kefeektifan organisasi dalam mencapai 
tujuannya. Sedangkan fungsi seorang pemimpin (Yukl 2005, Toor dan Ogunlana, 2008) adalah mengembangkan visi dan misi, mengembangkan pengaruh melalui budaya, menerapkan perubahan, melakukan inovasi dan pembelajaran dalam rangka mencapai tujuan organisasi secara efektif.

Banyak penelitian yang mendukung adanya hubungan yang positif antara kepemimpinan dengan kinerja melalui variabel moderator kompetensi dan komitmen. Chalhoub (2010) menyatakan pengaruh variabel kompetensi wirausaha, kompensasi, evaluasi kinerja dan partisipasi terhadap kinerja. Hasil penelitian menunjukkan bahwa kompetensi wirausaha, kompensasi dan evaluasi kinerja berpengaruh positif dan signifikan sedangkan partisipasi tidak berpengaruh nyata, serta kinerja bisnis sangat tergantung pada inovasi, maka kepemimpinan diharapkan dapat mengembangkan kompetensi wirausaha. Tahir dan Bakar (2010) - menyimpulkan bahwa: (a) kompetensi inti untuk manajer keuangan di Malaysia adalah Leadership, team building, communication, dan pelatihan, (b) kompetensi manajer keuangan pada tingkat fair sampai good dan belum mencapai outstanding, dan (c) mengingat pentingnya kepemimpinan, dan tingkat kompetensi yang ada, maka pemberian training untuk meningkatkan kompetensi menjadi suatu kebutuhan.

Brown (2009) menyatakan tentang manajemen SDM yang berhubungan dengan paradigma SDM sebagai aset terhadap profitabilitas dan daya saing perusahaan. Paradigma SDM sebagai aset dicerminkan dengan lima indikator yaitu: pengembangan kemampuan kepemimpinan, optimalisasi peran SDM, membangun keterlibatan SDM yang lebih besar, memberikan akses informasi yang lebih banyak, dan membangun kapasitas pembelajaran. Sedangkan profitabilitas diukur dari tingkat keuntungan, sedangkan daya saing dari peningkatan pangsa pasar. Hasil penelitian ini menunjukkan bahwa tingkat partisipasi yang tinggi yaitu di atas 2.5 dari skala 1 sampai 4 menghasilkan kinerja yang sangat baik dibandingkan dengan tingkat partisipasi di bawah 2.5.

Dalam hal penelitian dalam bidang jasa pendidikan ada beberapa hasil penelitian yang menunjukkan pentingnya kepemimpinan dalam rangka peningkatan daya saing organisasi di Indonesia. Sugiyanto (2008) menyimpulkan bahwa: (1) terdapat kontribusi yang positif dan signifikan gaya kepemimpinan kepala sekolah yang efektif terhadap keberhasilan sekolah; (2) terdapat kontribusi yang positif signifikan iklim sekolah yang kondusif terhadap keberhasilan sekolah; (3) terdapat kecerdasan emosional kepala sekolah memiliki kontribusi yang positif dan signifikan terhadap keberhasilan sekolah. Kepala sekolah yang memiliki kecerdasan emosional tinggi dapat mendorong terciptanya iklim sekolah yang kondusif dan mampu menerapkan pola kepemimpinan sesuai dengan tingkat kematangan bawahan; (4) secara bersama-sama terdapat kontribusi yang positif signifikan gaya kepemimpinan kepala sekolah, iklim sekolah, dan kecerdasan emosional kepala sekolah terhadap keberhasilan sekolah.

Soemantri (2009) menyatakan bahwa tata kelola Perguruan Tinggi yang efektif yaitu yang berkesesuaian dengan sasaran, tujuan serta budaya organisasi akan memberi kontribusi terhadap keberhasilan Perguruan Tinggi. Pemimpin harus komitmen pada pelaksanaan mewujudkan visi dengan misi yang diembannya. Dengan demikian keberhasilan organisasi tidaklah ditentukan semata-mata hanya oleh pemimpin, juga tidak ditentukan hanya oleh tata kelola (good governance) yang baik, namun ditentukan oleh berbagai faktor yaitu kepemimpinan, kematangan sub-ordinat, tim kerja, dan semangat wirausaha.

Sumidjo (2009) menyatakan bahwa penampilan kepemimpinan kepala sekolah adalah prestasi atau sumbangan yang diberikan oleh kepemimpinan seorang kepala 
sekolah, baik secara kualitatif maupun kuantitatif yang terukur dalam rangka membantu tercapainya tujuan sekolah. Penampilan kepemimpinan kepala sekolah ditentukan oleh faktor kewibawaan, sifat dan keterampilan, perilaku maupun fleksibilitas pemimpin. Fungsi kepemimpinan kepala sekolah berhasil memberdayakan segala sumber daya sekolah untuk mencapai tujuan sesuai dengan situasi, diperlukan seorang kepala sekolah yang memiliki kemampuan profesional yaitu: kepribadian, keahlian dasar, pengalaman, pelatihan dan pengetahuan profesional, serta kompetensi administrasi dan pengawasan.

Berdasarkan pada pemikiran Bass (2000) model dalam penelitian dapat digambarkan sebagai berikut:

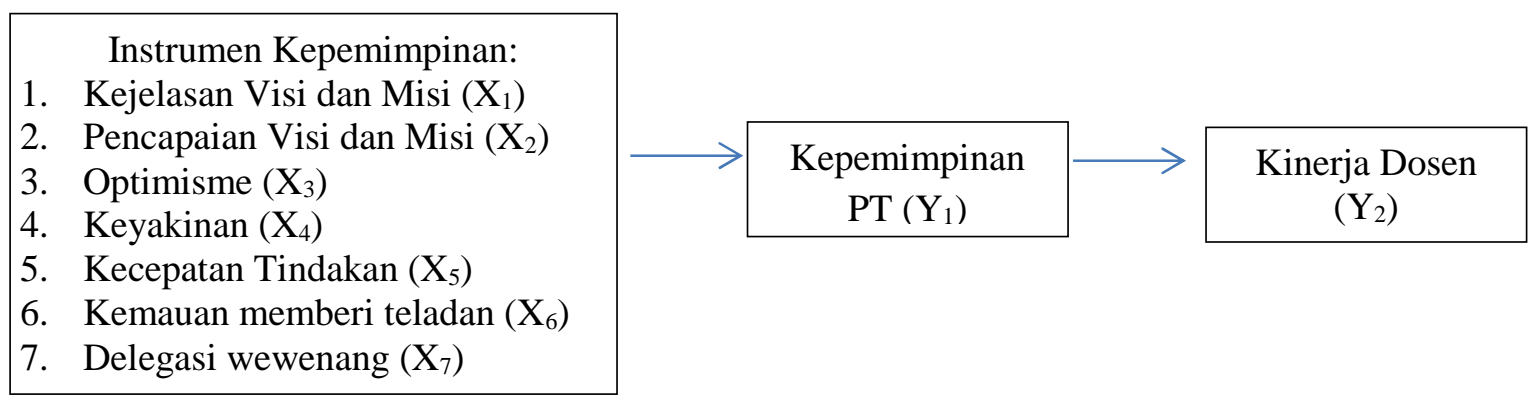

Kinerja dosen di pengaruhi oleh kemampuan kepemimpinan, dan kemampuan kepemimpinan berdasarkan tujuh variable yang dikemukan oleh Bass (2000) yaitu kejelasan visi dan misi, pencapaian visi dan misi, optimism, keyakinan, kecepatan tindakan, kemampuan member teladan dan delegasi wewenang. Hipotesa penelitian ini adalah:

(1) terdapat pengaruh positif dan signifikan kemampuan kepemimpinan terhadap kinerja dosen.

(2) terdapat pengaruh positif dan signifikan variable kepemimpinan yang terdiri variabel kejelasan visi dan misi, pencapaian visi dan misi, optimism, keyakinan, kecepatan tindakan, kemampuan member teladan dan delegasi wewenang terhadap kemampuan kepemimpinan terhadap kinerja dosen.

\section{METODE}

Penelitian ini dilakukan di dua perguruan tinggi yaitu satu PTN (perguruan tinggi negeri) dan satu PTS (perguruan tinggi swasta) di Jakarta. Penelitian dilakukan selama satu tahun (November 2011 sampai November 2012). Jumlah sampel dalam penelitian ini sebanyak 60 sampel yang terdiri 30 dosen di PTN dan 30 dosen di PTS. Pemilihan sampel dilakukan secara proportional stratified random sampling berdasarkan pada jenjang kepangkatan akademik yaitu asisten ahli, lektor, lektor kepala dan guru besar.

Pengukuran variable dalam penelitian ini menggunakan skala likert yang digunakan untuk mengukur sikap, pendapat dan persepsi seseorang atau kelompok tentang sebuah fenomena (Lind, Marchal dan Mason, 2002). Skala likert digunakan untuk mengukur variable kinerja dan variable kepemimpinan. Indikator kinerja dosen berdasarkan Konsep Tridarma Perguruan Tinggi yang mencakup antara lain: 


\begin{tabular}{cll}
\hline Variabel $\mathrm{Y}_{2}$ & & \multicolumn{1}{c}{ Indikator } \\
\hline \multirow{3}{*}{ Kinerja Pengajaran } & 1 & Persiapan bahan perkuliahan \\
& 2 & Pengajaran dan evaluasi perkuliahan \\
& 3 & Kepuasan mahasiswa terhadap pengajaran \\
& 1 & Jumlah Penelitian \\
Penelitian dan & 2 & Jumlah Jurnal \\
Publikasi & 3 & Jumlah Seminar \\
& 1 & Jumlah Pengabdian Masyarakat \\
Pengabdian & 2 & Jumlah publikasi pengabdian masyarakat \\
masyakarat & 3 & Jumlah organisasi sosial yang dibina \\
\hline
\end{tabular}

Indikator Kepemimpinan berdasarkan instrumen yang dikembangkan Bass (2000) mencakup:

\begin{tabular}{|c|c|c|}
\hline Variabel & & Indikator \\
\hline $\mathrm{X}_{1}$ & 1 & Kemampuan merumuskan visi dan misi \\
\hline \multirow{3}{*}{$\begin{array}{l}\text { (Tingkat kejelasan visi } \\
\text { dan misi) }\end{array}$} & 2 & Memiliki rasa yang kuat terhadap pencapaian visi dan misi \\
\hline & 3 & Kemampuan menepati visi dan misi di masa depan \\
\hline & 1 & $\begin{array}{l}\text { Kepemimpinan ide-ide baru untuk memecahkan masalah } \\
\text { yang ada }\end{array}$ \\
\hline \multirow{4}{*}{$\begin{array}{l}\mathrm{X}_{2} \\
\text { (Tingkat pencapaian visi } \\
\text { dan misi) }\end{array}$} & 2 & Tingkat antusias terhadap apa yang ingin dilakukan \\
\hline & 3 & $\begin{array}{l}\text { Mementingkan kepentingan organisasi dibanding } \\
\text { kepentingan pribadi }\end{array}$ \\
\hline & 1 & Tingkat optimisme mengenai masa depan organisasi \\
\hline & 2 & Tingkat keyakinan bahwa tujuan organisasi akan tercapai \\
\hline \multirow{2}{*}{$\begin{array}{c}\mathrm{X}_{3} \\
\text { (Tingkat optimisme) }\end{array}$} & & $\begin{array}{l}\text { Tingkat kekuatan dan keyakinan tentang pencapaian } \\
\text { tuiuan }\end{array}$ \\
\hline & 3 & Nilai-nilai yang penting untuk membangun organisasi \\
\hline \multirow{2}{*}{$\begin{array}{c}\mathrm{X}_{4} \\
\text { (Tingkat keyakinan) }\end{array}$} & & Konsekuensi moral dan etika dalam pengambilan \\
\hline & $\begin{array}{l}2 \\
1\end{array}$ & $\begin{array}{l}\text { keputusan } \\
\text { Kemampuan mencegah suatu masalah }\end{array}$ \\
\hline \multirow[t]{2}{*}{$\begin{array}{l}\mathrm{X}_{5} \\
\text { (Tingkat kecepatan } \\
\text { tindakan) }\end{array}$} & 2 & $\begin{array}{l}\text { kebanggaan terhadap setiap orang lain dalam organisasi } \\
\text { Kemampuan menunjukkan bahwa suatu masalah harus } \\
\text { dicegah sebelum menjadi masalah yang kritis }\end{array}$ \\
\hline & 1 & $\begin{array}{l}\text { Kemampuan memberikan bantuan dan bimbingan kepada } \\
\text { orang }\end{array}$ \\
\hline \multirow{4}{*}{$\begin{array}{c}\mathrm{X}_{6} \\
\text { (Tingkat kemauan } \\
\text { memberi teladan) }\end{array}$} & 2 & Kemampuan menjaga organisasi dan mencegah kerusakan \\
\hline & 3 & Kemampuan melihat masalah dari berbagai sudut pandang \\
\hline & 4 & Tingkat kepuasan saat harapan orang lain terpenuhi \\
\hline & 1 & $\begin{array}{l}\text { Menetukan siapa yang bertanggungjawab terhadap } \\
\text { pencapaian target }\end{array}$ \\
\hline \multirow{2}{*}{$\begin{array}{l}\mathrm{X}_{7} \\
\text { (Tingkat kemauan dalam } \\
\text { memberi delegasi } \\
\text { wewenang) }\end{array}$} & 2 & $\begin{array}{l}\text { Kemampuan memperlakukan orang lain sebagai individu } \\
\text { dan tidak hanya seperti anak buah }\end{array}$ \\
\hline & 3 & Menyarakan cara baru untuk menyelesaikan tugas \\
\hline
\end{tabular}

Sebelum dilakukan penelitian, maka kuisioner dilakukan ujicoba reabilitas dan validitas sebagaiman ketentuan dalam statistika. Setelah data ditabulasi dilakukan uji statistika yang 
mencakup uji normalitas, uji multikolinier, uji heteroskedastisitas. Metode analisis dalam penelitian ini menggunakan persamaan regresi berganda dan diolah dengan menggunakan SPSS. Persamaan dalam penelitian ini adalah sebagai berikut:

$$
Y_{1}=a_{1}+b_{1} X_{1}+b_{2} X_{2}+b_{3} X_{3}+b_{4} X_{4}+b_{5} X_{5}+b_{6} X_{6}+b_{7} X_{7}+
$$

dimana: $\mathrm{Y}_{1}=$ tingkat kemampuan kepemimpinan; $\mathrm{X}_{1}=$ tingkat kejelasan visi dan misi; $\mathrm{X}_{2}=$ tingkat pencapaian visi dan misi; $\mathrm{X}_{3}=$ tingkat optimisme; $\mathrm{X}_{4}=$ tingkat keyakinan; $\mathrm{X}_{5}=$ tingkat kecepatan tindakan; $\mathrm{X}_{6}=$ tingkat kemauan memberi teladan; $\mathrm{X}_{7}=$ tingkat kemauan delegasi wewenang; $=$ standar eror.

dan Persamaan Kinerja dengan Tingkat Kemampuan Kepemimpinan adalah:

$$
\mathrm{Y}_{2}=\mathrm{a}_{2}+\mathrm{c}_{1} \mathrm{Y}_{1}+
$$

dimana: $\mathrm{Y}_{1}=$ tingkat kemampuan kepemimpinan; $\mathrm{Y}_{1}=$ tingkat kinerja dosen dalam tridarma; $=$ standar eror

\section{HASIL DAN PEMBAHASAN}

Hasil penelitian berupa persamaan regresi berganda disajikan pada Tabel 1 dan 2 . Tabel 1 menunjukkan persamaan antara fungsi-fungsi kepemimpinan dan efektivitas atau tingkat kemampuan kepemimpinan. Sebelum melakukan regresi berganda, dilakukan uji normalitas, uji multikolineritas dan heteroskedastisitas serta uji validitas dan reabilias atas data. Secara statistik seluruh variable bebas atau independent berpengaruh nyata terhadap variable tidak bebas atau dependent. Untuk melihat kesesuaian model maka dapat dilihat dari nilai koefisien determinasi dan anova. Koefisien determinasi $\left(\mathrm{R}^{2}\right)$ sebesar $99,1 \%$ menunjukkan kemampuan menjelaskan dari keseluruhan variable bebas terhadap variabel tidak bebas mencapai $99,1 \%$. Dengan demikian variable bebas sangat baik menjelaskan variable tidak bebas. Uji Anova dapat dilihat dari uji $\mathrm{F}$ yaitu nilai F-hitung sebesar 364,295 dan lebih besar dari F-tabel yaitu 4.3 dengan demikian dapat disimpulkan bahwa seluruh variabel bebas berpengaruh nyata atau signifikan terhadap variable tidak bebas. Dengan demikian dapat disimpulkan bahwa model yang dirumuskan adalah sangat baik dan tepat baik dari nilai korelasi, koefisien determinasi dan uji F.

Analisis statistik secara parsial menunjukkan bahwa pengaruh seluruh variable bebas terhadap tidak bebas adalah positif, sehingga setiap kenaikan dari varibael endogenus akan berdampai positif terhadap variable tidak bebas. Nilai dari t-hitung juga menunjukkan bahwa seluruh variable berpengaruh nyata, dimana nilai t-hitung lebih besar dari t-tabel pada taraf nyata $5 \%$ yaitu 2.074 dan taraf nyata $1 \%$ yaitu 2.819 .

Variabel yang sangat berpengaruh nyata terhadap tingkat kepemimpinan adalah tingkat kemampuan memberi teladan. Nilai t-hitung sebesar 20.709 dan nyata pada taraf $1 \%$. Setiap peningkatan satu tingkat kemampuan dalam memberi teladan akan mampu meningkatkan tingkat kemampuan dalam meningkatkan kinerja dosen sebesar 0.2 atau dampaknya sebesar 20\%. Nilai koefisien tingkat kemampuan memberi teladan ini juga paling besar, dan ini menunjukkan variable yang sangat penting.

Hakikat kepemimpinan di perguruan tinggi. Kepemimpinan ini masih sesuai dengan kondisi di Indonesia, dimana filosofi kepemimpinan sebagaimana dikemukakan oleh Ki. 
Hajar Dewantara adalah Ing Ngarso Sung Tulodo, atau pemimpinan itu di depan memberikan teladan.

Tabel 1. Hasil Regresi Berganda Persamaan Tingkat Kemampuan Kepemimpinan

\begin{tabular}{lrrr}
\hline Keterangan & Koefisien & t-hitung & Probabilitas $(\mathrm{p})$ \\
\hline sep & 0.184 & 2.335 & 0.029 \\
Kejelasan Visi dan Misi & 0.076 & 5.790 & 0.000 \\
Pencapaian Visi dan Misi & 0.100 & 9.462 & 0.000 \\
Optimisme & 0.142 & 10.745 & 0.000 \\
Keyakinan & 0.097 & 7.252 & 0.000 \\
Kecepatan Tindakan & 0.151 & 12.142 & 0.000 \\
Memberi Teladan & 0.200 & 20.709 & 0.000 \\
Delegasi Wewenang & 0.185 & 10.842 & 0.000 \\
Nilai F-hitung & 364.295 & F-tabel & 2.46 \\
Nilai R & 0.996 & & \\
Nilai R & 0.991 & & \\
$* *$ & \multicolumn{3}{c}{ nyata dalam taraf 5\% } \\
$*$ & \multicolumn{3}{c}{ nyata dalam taraf 1\% } \\
\hline
\end{tabular}

Pada kondisi masyarakat termasuk kalangan perguruan tinggi bersifat paternalistik, maka seorang bawahan bukan mengikuti apa yang dikatakan pemimpinnya, namun akan mengikuti apa yang dilakukan pemimpinnya. Hal ini sesuai dengan pendapat Bass (2000) terkait pemimpin tranformasional yaitu pemimpin yang mampu untuk: (a) menstimulasi semangat para dosen untuk melihat pekerjaan dalam tidarma dari beberapa perspektif baru, (b) menurunkan visi dan misi perguruan tinggi kepada tim dosen untuk membangun kontribusi setiap anggota organisasi, (c) mengembangkan anggota organisasi pada tingkat kemampuan dan potensial yang lebih tinggi, dan (d) memotivasi dosen untuk melihat pada kepentingannya masing-masing, sehingga dapat bermanfaat bagi kepentingan perguruan tinggi. Hal ini sesuai dengan pendapat Yukl (2005) bahwa seorang pemimpin harus mampu menujukkan contoh terutama kejujuran dan kepercayaan atau Establish Trust and Demonstrate Integrity yaitu seorang pemimpin perguruan tinggi mamu berbuat dan berperilaku jujur serta mampu menunjukkan kepada anggotanya perilaku jujur dan perbuatan atau tindakan dalam organisasi. Establish Trust and Demonstrate Integrity tersebut mencakup: (a) mampu menunjukkan sikap dan perilaku kejujuran, (b) mampu mengambil sikap berani dan hormat pada hal-hal yang prinsip, (c) melakukan apa yang dikatakan, (d) berbicara dengan bukti dan pengalaman.

Variabel kedua yang terpenting adalah tingkat kecepatan mengambil tindakan. Variable ini mempunyai nilai t-hitung 12.142 atau nyata pada taraf $1 \%$ dan nilai koefisien sebesar 0.151 yang berarti setiap kenaikan satu tingkat kecepatan mengambil tindakan akan meningkatkan kemampuan kepemimpinan dalam meningkatkan kinerja sebesar 0.151 atau $15,1 \%$. Variable ini termasuk dalam kompetensi bagaimana seorang pemimpin mampu mencegah suatu masalah, dan mengambil keputusan cepat sehingga masalah tidak menjadi kritis serta mengambil tindakan perbaikan berkelanjutan. Pengambilan keputusan akan cepat menurut Hammond, et al (1999) antara lain: (a) memahami masalah dengan benar dan membuat keputusan dengan benar serta menghilangkan asumsi dan opini, (b) mengambil keputusan dengan tujuan yang spesifik, (c) menciptakan alternative pada 
setiap keputusan, dan (d) memahami setiap konsekuensi dari setiap keputusan dan tindakan.

Variabel ketiga yaitu kemampuan memberikan delegasi wewenang dimana nilai thitung 10.842 atau nyata pada taraf $1 \%$ dan nilai koefisien regresi sebesar 0.185 . Delegasi wewenang mencakup aspek kepercayaan dan rentang kendali organisasi. Setiap dosen yang diberikan wewenang menunjukkan adanya kepercayaan dari atasan, dan semakin memperpendek rentang kendali organisasi sehingga komunikasi dan umpan balik dapat dilakukan secara cepat. Menjadi hal yang tidak biasa di perguruan tinggi, dimana seorang pemimpin terbiasa bekerja dengan kemampuan sendiri dari melahirkan konsep sampai implementasi. Hal ini sangat menghambat bagi peningkatan kinerja organisasi. Pembentukan team work dan delegasi wewenang yang lebih besar kepada tingkat yang lebih rendah akan meningkatkan kinerja dosen. Menurut Muir (1995) pencapaian kinerja organisasi berkaitan dengan bagaimana bersama-sama sumber daya lain sehingga pekerjaan yang dilakukan secara efisien dan tujuan terpenuhi dalam skala waktu yang ditetapkan. Hal yang sangat penting untuk memberikan dorongan atau motivasi kepada orang lain adalah dengan menunjukkan kepercayaan melalui delegasi wewenang. Pendelegasian yang efektif memberikan manfaat bagi kedua pihak baik organisasi maupun individu. Pendelegasian antara atasan dan bawahan harus memperhatikan faktor kemampuan, kekuatan dan kelemahan dari bawahan dan mengalokasikan pekerjaan yang sesuai.

Variabel ke-empat adalah optimisme dimana nilai t-hitung sebesar 10.742 dan nyata pada taraf nyata $1 \%$ serta nilai koefisien regresi besar 0.142 atau kenaikan 1 tingkat optimism akan meningkatkan kemampuan kepemimpinan dalam meningkatkan kinerja sebesar 14,2\%. Optimism seorang pemimpin akan membawa keyakinan bagi anggota organisasi termasuk dosen. Keyakinan pemimpin mencakup keyakinan masa depan organisasi, keyakinan bahwa target akan tercapai dan keyakinan kekuatan sumberdaya organisasi dalam mencapai tujuan. Greenberg dan Arakawa (2007) menyatakan optimisme dan harapan akan menyebabkan pemimpin lebih tahan terhadap depresi ketika peristiwa buruk terjadi, kinerja yang lebih baik di tempat kerja, khususnya dalam pekerjaan yang bersifat menantang, dan kesehatan fisik yang lebih baik. Dalam lingkungan yang cepat berubah dan tidak pasti, seorang pemimpin dan karyawan perlu optimisme yang lebih tinggi dari sebelumnya untuk tidak hanya mengatasi, tetapi untuk berinovasi dan berkembang. Pemimpin organisasi memiliki pengaruh pada keterlibatan rasa optimisme dan kinerja karyawan, dan sadar dapat menggunakan pengaruh ini untuk mendorong karyawan sebagai tenaga kerja produktif.

Variabel lainnya seperti pencapaian visi dan misi, keyakinan, dan kejelasan visi dan misi juga mempunyai pengaruh yang nyata pada taraf nyata $1 \%$. Namun demikian, untuk membangun kinerja organisasi yang sangat baik, fungsi kepemimpinan perguruan tinggi dapat fokus pada 4 fungsi yaitu pemimpin yang mampu memberi teladan dalam tridarma, pemimpin yang mampu mengambil keputusan yang cepat, pemimpin yang mampu memberikan delegasi wewenang dengan tepat serta mempunyai tingkat optimism yang tinggi.

Persamaan kedua dalam penelitian ini adalah hubungan antara tingkat kemampuan kepemimpinan dengan kinerja dosen dalam tridarma. Hasil regresi disajikan pada Tabel 2. Tabel 2 menunjukkan bahwa koefisien korelasi sebesar 0.829 yang artinya hubungan antara variabel kepemimpinan dengan variabel kinerja dosen sebesar 82,9\% dan kemampuan variabel kepemimpinan dalam menjelaskan variabel kinerja dosen sebesar 
68,7\%. Pengaruh variabel kepemimpinan terhadap kinerja juga nyata dengan ditunjukkan nilai F-hitung sebesar 47.700 dan lebih besar dari F-Tabel 2 Dengan demikian variabel kepemimpinan secara bersama-sama pengaruhnya nyata terhadap variable kinerja dosen.

Tabel 2. Hasil Regresi Persamaan Kinerja dengan Kepemimpinan

\begin{tabular}{lrlrr}
\hline Keterangan & Koefisien & & t-hitung & \multicolumn{2}{c}{ Probabilitas $(\mathrm{p})$} \\
\hline Intersep & 3.309 & & 4.226 & 0.049 \\
Kepemimpinan & 0.142 & & 6.910 & 0.000 \\
Nilai F-hitung & 47.700 & F-tabel & & 4.3 \\
Nilai R & 0.829 & & \\
Nilai R & 0.687 & & \\
$* *$ & & nyata dalam taraf 5\% & \\
$*$ & & nyata dalam taraf 1\% & \\
\hline
\end{tabular}

Variabel kepemimpinan mempunyai nilai t-hitung sebesar 6,910 dan lebih besar dari t-tabel pada taraf nyata $1 \%$ yaitu 2.819. Dengan demikian dapat disimpulkan bahwa pengaruh kepemimpinan terhadap kinerja adalah nyata. Hal ini berimplikasi nyata pada system kepemimpinan dalam perguruan tinggi. Pemimpin perguruan tinggi mempunyai pengaruh yang sangat kuat dalam meningkatkan dan mempengaruhi kinerja dosen. Peningkatan kinerja dalam tridarma yaitu pendidikan, penelitian dan publikasi serta pengabdian kepada masyarakat membutuhkan kepemimpinan perguruan tinggi yang kuat. Sistem pemilihan kepemimpinan di perguruan tinggi diharapkan dapat menghasilkan kepemimpinan yang sesuai yaitu mampu memberikan keteladanan, kemampuan mengambil keputusan cepat, mampu memberikan delegasi wewenang dan tingkat optimism yang tinggi. Hal ini sesuai dengan hasil penelitian Handoyo (2010 yang menyatakan bahwa struktur organisasi dan pejabatnya, tingkat kebijaksanaan, dan pelayanan adalah dimensi terpenting dalam kepemimpinan di perguruan tinggi.

\section{PENUTUP}

Simpulan. (1) Peningkatan dayasaing bangsa Indonesia sangat berkorelasi dengan dayasaing perguruan tinggi terutama terkait dengan pendidikan tinggi dan pelatihan, kesiapan teknologi dan inovasi. (2) Peningkatan dayasaing perguruan tinggi sangat terkait dengan kenerja dosen dalam tridarma yaitu pendidikan, penelitian dan publikasi, pengabdian kepada masyarakat dan kinerja dosen sangat dipengaruhi oleh tingkat kemampuan kepemimpinan dalam membangun kompetensi dan komitmen. (3) .Kepemimpinan di perguruan tinggi yang mampu meningkatkan kinerja dosen adalah kepemimpinan yang mampu memberikan teladan, mengambil keputusan dengan cepat, memberikan delegasi wewenang dengan baik serta tingkat optimism yang tinggi.

Saran. (1) Disarankan kepada manajemen pendidikan tinggi untuk mengembangkan system pemilihan kepemimpinan di perguruan tinggi yang memastikan bahwa setiap pemimpin mampu memberikan teladan dengan mengembangkan system assessment center dan tidak semata pada aspek demokrasi. (2) Penelitian masih mempunyai keterbatasan baik dalam jumlah sampel maupun analisis. Penelitian lanjutan diharapkan dapat menerapkan analisis yang menggunakan SEM dengan sampel yang jauh lebih besar. 
Penelitian lanjutan juga disarankan menggunakan pemikiran teori kepemimpinan asli Indonesia seperti kepemimpinan Ki Hajar Dewantoro untuk membandingkan dengan teori kepemimpinan model Bass.

\section{DAFTAR RUJUKAN}

Alves, J.C., C. C. Manz., D. A. Butterfield. (2008) Developing Leadership Theory in Asia: The Role of Chinese Philosophy. Institute of Behavioral and Applied Management: Vol. 1 (1) page 3-37.

Bachtiar, N. (2013) Daya Saing Perguruan Tinggi. Padang. Fakultas EkonomiUniversitas Andalas.

Bass, B.M. (2000) "Predicting Unit Performance by Assessing Tranformational and Transactional Leadership”. Journal of Applied Psychology: Vol 88 (2) page:207218.

Brodjonegoro, S. S., (2008) "Beberapa Pemikiran Dalam Rangka Peningkatan Mutu dan Daya Saing Perguruan Tinggi”, Makalah. Malang: Universitas Brawidjadja.

Brown, A. S. (2009) "Thinks of Workers as Assets". Mechanical Engineering Journal: Vol 131 (1) page: 361-373.

Chalhoub M.S. (2010) "Innovation Management and Thought Leadership - A Cultural Requirement in a Global Competitive Environment". The Journal of American Academy of Business, Cambridge, Vol. 16 (1) page 99-110.

Drago, W. A., C. Clemets. (1999) Leadership Characteristics and Strategic Planning. Management Research News: Vol 22 (1) page:11-18.

Greenberg, M. and D. Arakawa. (2007) Optimistic Managers \& Their Influence on Productivity \& Employee Engagement in a Technology Organization. International Coaching Psychology Review: Vol. 2 (1) page 1-32.

Hamilton, F. (2005) High Performance Governance: Structure, Leadership, Incentive. Boston. McGraw Hill Irwin.

Hammond, J. et al. (1999) Smart Choices: A Practical Guide to Making Better Decisions. Boston: Harvard Business School Press.

Handoyo, S. (2010) "Pengukuran Servant Leadership Sebagai Alternatif Kepemimpinan di Institusi Pendidikan Tinggi Pada Masa Perubahan Organisasi”. Makara, Jurnal Sosial Humaniora: Vol 14 (2) page 130-140.

Hughes, R.L., R.C. Ginnett, G.J. Curphy. (2002) Leadership, Enhancing the Lessons of Experience. Boston. McGraw Hill Irwin.

Javidan, M., Dorfman, P. W., de Luque, M. S., \& House, R. J. (2006) In the Eye of the Beholder: Cross Cultural Lessons in Leadership from Project GLOBE. The Academy of Management Perspectives, 20(1), 67-90.

Langitan, Benyamin. (2012) Riset untuk Peningkatan Daya Saing Perguruan Tinggi. Makalah Rakornas Penelitian dan Pengembangan Masyarakat, Kementrian Pendidikan dan Kebudayaan RI. Yogyakarta, 12 Januari 2013.

Lind, A. D., W. G. Marchal, R. D. Mason. (2002) Statistical Techniques in Business and Economic. Toronto. McGraw-Hill Companies.

Meyer R. C., and Herscovitch. (2001) An Integration Model of Organizational Trust. Academy of management review, Vol 20 (3) page 299-326. 
Muir, J. (1995) “Effective Management Through Delegation”. Work Study Joournal: Vol. 44 (7) page 6-7.

Schwab, K. (2012) The Global Competitiveness Report 2012-2013. World Economic Forum - Geneva Switzerland.

Schimmoeller L. J. (2005) The Effects of Organizational Culture on the Dominant Style of Leadership in an Organization. School of Business and Economic, Lyncbrugh College.

Scimago. (2013) Journal and Country Rank 1996-2011. http://www.scimagojr.com

Soemantri, G. (2009) Tantangan Kepemimpinan Dalam Perspektif Perguruan Tinggi di Indonesia, Makalah. Jakarta. Universitas Indonesia.

Sugiyanto. (2008) "Kontribusi Gaya Kepemimpinan, Iklim Sekolah, dan Kecerdasan Emosional Kepala Sekolah terhadap Keberhasilan Sekolah menurut Persepsi Guru SMK Negeri dan/Swasta di Kota Blitar", Disertasi. Malang. Universitas Negeri Malang.

Sumidjo, W. (2009) "Hubungan Kepemimpinan Kepala Sekolah dan Sikap Guru terhadap Pekerjaan dengan Kompetensi Profesional Guru”, Thesis. Jakarta. Universitas Negeri Jakarta.

Susbandono, P.M. (2011) Anjing Hachiko, dan Hilangnya Kemanusiaan Kita. Kaifa (Mizan Group). Jakarta.

Tahir, I.M., N. M. A. Bakar. (2010) "Managerial Competencies in the Malaysian Financial Services Sector". Interdisciplinary Journal of Contemporary Research in Business, Vol 1 (12) page 132-141.

The Globe. (2007) Culture and Leadership across the World: The GLOBE Book of InDepth Studies of 25 Societies. Wharton School of Business

Toor, S. R., S. O. Ogunlana. (2008) "Leadership Skills and Competencies for Crosscultural Construction Projects". International Journal of Human Resources Development and Management: Vol. 8 (3) page 192-215.

Winston, B. E., B. Ryan. (2008) Servant Leadership as a Human Orientation. International, Journal of Leadership Studies: Vol 3 (2) page 212-222.

Yukl, G. (2005) Kepemimpinan dalam Organisasi (Terjemahan). Jakarta: Penerbit Indeks. 